\title{
Phonological Activation in Korean Word Recognition between Korean Native Speakers and Japanese- Korean and Chinese-Korean Bilingual Speakers: Evidence from Event-Related Potentials
}

\author{
Dongran Won, Hyun Sub Sim \\ Department of Communication Disorders, Ewha Womans University, Seoul, Korea
}

Correspondence: Hyun Sub Sim, PhD Department of Communication Disorders, Ewha Womans University, 52 Ewhayeodae-gil, Seodamun-gu, Seoul 03760, Korea Tel: $+82-2-3277-2120$

Fax: +82-2-3277-2122

E-mail: simhs@ewha.ac.kr

Received: January 5, 2020

Revised: February 5, 2020

Accepted: February 14, 2020

This work was supported by BK21plus project by Korea Government (NRF-1-2019-0405-001-1).

\begin{abstract}
Objectives: The purpose of this study is to explore the differences of real-time processing in word recognition according to the application of Korean-specific phonological rules among Korean native speakers, Japanese-Korean bilinguals, and Chinese-Korean bilinguals through the Event-Related Potentials (ERP) analysis. Methods: Subjects were 15 native Korean speakers and 27 bilingual speakers: 13 Japanese-Korean and 14 Chinese-Korean speakers who learning Korean as a second language. They were asked to judge whether the pronunciation of the visual stimulus word was identical to the corresponding auditory stimulus word. Results: All three groups showed a significant difference in both the judgment accuracy (\%) and reaction time (ms) when the phonological rules were applied. In other words, the judgment accuracy was higher and reaction time was faster under the condition of applying the phonological rules than the condition without the phonological rules. ERP analysis after the visual stimulus presentation show that a significant difference among three groups and between two conditions was in amplitudes of N250. After the auditory stimulus, a significant difference between two conditions was found in amplitudes of N400. Conclusion: The results indicated that by increasing exposure time to Korean and learning more words with the phonological rules, they are likely to make identical grapheme-phoneme processing to that of native speakers.
\end{abstract}

Keywords: Korean word recognition, bilinguals, ERP, N250, P200, N400
한국어는 자소-음소 대응규칙(grapheme-phoneme correspondence rules)에 따라 비교적 일관성을 갖는다. 하지만 두 음절 이상 의 단어를 읽을 때에는 음절과 음절 사이에서 음운이 변화하는 현 상이 일어난다. 음운이 변화하는 현상에 규칙성이 있다. 이를 음운 규칙이라고 부르며, 자연스럽게 한국어를 읽기 위해서는 음운규칙 을 이해하고 적용할 수 있는 능력이 필요하다. 한국어 원어민의 경우 교과과정에 음운규칙이 포함되어 있어 초등학교 고학년에 이르면 성인과 비슷한 수준의 음운규칙 능력을 보인다(Lim \& Kim, 2008).

한국어를 제 2 언어로 습득하는 이중언어 사용자(bilingual)에게 한국어 음운규칙은 한국어 습득을 어렵게 하는 요소 중 하나이다. 언어권에 따른 음운규칙 적용의 오류를 비교한 $\mathrm{Heo}$ (2012) 연구에
따르면, 음운규칙이 많지 않은 중국어를 모국어로 하는 한국어 이 중언어 사용자는 비음화와 유음화에서 가장 많은 오류를 보인다. 한국어와 문법적으로 유사성이 많은 일본어를 모국어로 하는 한 국어 이중언어 사용자의 경우에는 한국어를 상대적으로 쉽게 배 우지만 발음 학습에는 어려움을 보인다. 또한 타 언어권 이중언어 사용자와 달리 격음화에서 높은 오류를 보인다. 선행연구들은(Kim \& Baek, 2015; Heo, 2012; Rhee, Kim, \& Chang, 2007) 이러한 오류 의 원인으로 모국어와의 관계성 또는 음운론적 난이도 등을 제시 한다. 하지만 선행연구 모두가 행동분석을 하는 수준에서 진행되었 기에, 한국어 이중언어 사용자의 모국어에 따라 신경학적 측면에 서 언어처리에 어떠한 차이가 있는가를 확인할 수 없다는 한계점이 
있다. 따라서 본 연구는 한국어 원어민뿐만 아니라 한국어를 학습 하는 중국인과 일본인들의 한국어 음운규칙의 신경학적 처리과정 을 비교분석하기 위해 뇌파의 변화를 실시간으로 살펴볼 수 있는 사 건관련전위(event-related potentials, ERP) 연구를 실시하였다.

사건관련전위(ERP)는 인지적 처리가 요구되는 상황에서 자극이 제시된 후 특정 시간대에 발생하는 뇌파(Electroencephalogram, $\mathrm{EEG)}$ 를 평균화하여 얻는 값으로 뇌의 활동전위를 실시간으로 보여 준다. 따라서 시간에 따른 대뇌의 인지정보 처리과정을 완벽하게 측 정할 수 있다. 사건관련전위중 $\mathrm{N} 250$ 성분은 자극 제시 후 $250 \mathrm{~ms}$ 전 후에 음의 방향(negative)으로 정점이 보이는 사건관련전위로서, 시 각단어 재인 시 어휘처리 이전의 초기 음운처리 단계 즉, 자소-음소 대응처리를 반영한다고 알려져 있다. 선행연구들(Liu, Perfetti, \& Hart, 2003; Grainger \& Holcomb, 2009; Kwon, Nam, \& Lee, 2015)에 따르면 N250은 점화자극과 목표자극의 표기 또는 발음이 다를 경 우 활성화되어 나타난다. 예를 들어, 목표자극 '같이'와 관련성이 없 는 점화자극 ‘나무를 제시했을 경우가, 음운 또는 표기적으로 목표 자극과 관련있는 점화자극인 '가치'를 제시했을 경우 보다 크게 나 타난다는 것이다. P200 성분은 자극 제시 이후 $200 \mathrm{~ms}$ 대에 이르러 양의 방향(positive)으로 정점이 보이는 사건관련 뇌 전위 요인으로 서, 의미처리 이전에 나타나는 음운처리 관련 성분이며 표기나음운 이 일치할 때 가장 크게 나타난다(Liu et al., 2003). N400은 자극제시 이후 $400 \mathrm{~ms}$ 대에 이르러 음의 방향(negative)으로 정점을 보이는 사 건관련 뇌 전위 요인으로서, $\mathrm{N} 400$ 의 크기는 의미적 활성화와 밀접 한 관련이 있는 것으로 알려져 있다(Kwon \& Lee, 2016). 외국에서는 단어를 재인하는 동안의 음운 및 어휘처리에 대한 ERP 연구가 진행 되어왔다. Grainger, Kiyonaga와 Holcomb (2006)은 표기자극과 음 운 자극의 시간적 처리 과정을 살펴보았다. 이들은 표기정보가 유사 한 조건(예: ‘brain-BRAIN', 통제자극 ‘bosin-BRAIN')과 음운정보 가 유사한 조건(예: ‘brane-BRAIN', 통제자극 ‘brant-BRAIN')을 비 교하여 연구를 진행하였다. 그 결과, 각 조건 모두 통제자극에서 큰 $\mathrm{N} 250$ 을 보였다. 즉, $\mathrm{N} 250$ 은 음운이나 표기가 일치하는 조건에서 작 게 활성화되며, 음운이나 표기가 일치하지 않은 조건에서 크게 활성 화된 것이다. 두 조건에서 $\mathrm{N} 250$ 이 활성화된 결과는 시각 단어재인 을 하는 동안 하위어휘(sublexical) 처리를 반영하는 가설을 지지하 며, 시간처리과정에서 표기자극이 음운자극보다 먼저 선행되는 것 을 확인할 수 있었다. 스페인어와 영어를 사용하는 이중언어 사용자 를 대상으로 언어전환 시 사건관련전위를 살펴본 연구(Fengyang, Peiyao, Taomei, \& Judith, 2017)에 의하면, L1 단어가 L2 단어로 올바 르게 해석되어 있는지 판단하는 과제에서도 목표자극(예, perro, 스 페인어로 '개'를 뜻함)과 형태가 일치하는 자극(예, dot, 영어로 '개'
를 뜻하는 ' $\operatorname{dog}$ '와 형태가 일치)일 경우에 P200이 크게 활성화 되었 고 의미가 일치하는 경우(예, $\operatorname{dog}$ )에서는 N400이 작게 활성화가 되 었다. Hoshino, Midgley, Holcomb 그리고 Grainger (2010)는 일본어 와 영어를 사용하는 이중언어 사용자를 대상으로 L1과 L2 단어 자 극을 'L1-L1', 'L1-L2', 'L2-L1', 'L2-L2' 조건으로 제시하여 의미범주 판단과제를 진행했다. 그 결과, 모국어 조건(L1-L1), 제2언어 조건 (L2-L2)에서 N250과 N400의 활성화를 밝혔다.

최근 한국에서는 시각 단어재인 시 음운정보의 영향을 살펴본 연구(Kwon et al., 2015) 이외에, 의미와 무의미 단어의 음운규칙 적 용 여부에 따른 단어재인 과제를 실시하는 동안 뇌파를 분석한 연 구(Choi, 2017), L1-L2의 전환과정을 살펴본 연구(Kim, 2010) 등이 실시되었다. Kwon 등(2015)의 연구에서는 어휘판단과제를 사용하 여 점화자극에 따른 단어재인의 과정을 살펴보았다. 그 결과, 목표 자극(예, 녹말)과음운 및 표기와 관련이 없는 통제조건(예, 적감)을 점화자극으로 제시했을 때 N250의 큰 활성화가 관찰되었다. Choi (2017)의 연구에서는 의미와 무의미 단어를 사용하여 음운규칙 적 용 여부에 따른 단어재인 과정을 살펴보았다. 그 결과, 무의미 단어 에서 보다 의미 단어에서 P200, N250, N400의 활성화가 더 일어났 으며, 음운규칙이 적용되는 의미 단어 자극에서 N250이 작게 활성 화되었음을 보고하였다. 또한 Kim (2010)의 연구에서는 문장의 의 미적절성을 판단하는 과제를 사용하여 실험을 진행하였다. 그 결 과, 모국어 질의-응답 조건(L1-L1)에서 의미가 불일치할 경우 N400 이 활성화되었다. 외국어 답변 조건(L1-L2)에서는 N400이 나타났 으나 의미 일치 유무에 따라차이는 나타나지 않았다.

본 연구는 한국어 원어민과 외국어로 한국어를 습득한 일본어 및 중국어 이중언어 사용자를 대상으로 음운규칙 처리과정을 행 동분석과 뇌파 분석을 통해 살펴봄으로써, 일본인과 중국인이 한 국어 자소-음소 전환할 때 요구되는 음운규칙의 신경학적 처리과 정을 한국어 원어민과 비교하는데 목적을 두었다. 위에서 언급된 국내에서 진행된 선행연구들은 단어재인 과정을 시각적 측면에서 만 살펴보았거나, 비교집단을 설정하지 않았다. 따라서 본 연구는 한국어 이중언어 사용자와 한국어 원어민을 대상으로 음운규칙을 적용하여 읽어야 하는 단어를 시각자극으로 제시한 뒤에, 청각자 극을 제시하여, 피험자가 음운판단을 하는 방식으로 실험 설계함 으로써, 집단 간 행동분석 및 $\mathrm{ERP}$ 결과를 비교하고자 하였다. 이를 위해 본 연구는 (1) 한국어 원어민과 비교하여 일본어-한국어 및 중 국어-한국어 이중언어 사용자들이 실제로 한국어 음운규칙을 적 용하는데 얼마나 어려움을 보이는지를 정반응률과 반응시간을 통 해 행동분석을 하였고, (2) 음운규칙 적용 유무에 따른 ERP 특성 의 집단 간 비교를 N250, P200 및 N400을 중심으로 실시하였다. 


\section{연구방법}

\section{연구대상}

본 연구는 한국어 원어민 15 명(남자 2 명, 여자 13 명, 평균 연령 25 \pm 2.8 ), 일본어-한국어 이중언어 사용자 13 명(남자 0 명, 여자 13 명, 평균 연령 $23.4 \pm 4.2$ ), 중국어-한국어 이중언어 사용자 14 명(남자 2 명, 여자 12 명, 평균 연령 $22.4 \pm 3$ )으로 총 42 명이 참여하였다. 한국 어 원어민 화자의 경우 한국어를 모국어로 하는 서울 및 경기도에 거주하는 대학생과 직장인들로 선정하였다. 일본어-한국어 및 중 국어-한국어 사용자는 한국에 거주하면서 어학당 또는 대학에 소 속되어 한국어를 습득했거나 습득하고 있는 이중언어 사용자로 선 정하였다. 이중언어 사용자는 E-PRIME 형태의 선별검사를 진행 했다. 본 실험 전 기초 음운규칙에 대한 지식을 평가한 것으로 음운 규칙이 제대로 형성되어 있지 않으면 과제 진행이 어렵다고 판단되 었기 때문이다. 따라서, 선별검사에서 $70 \%$ 미만의 정반응률을 보 일 경우 실험에서 제외하였다. 이중언어 사용자 간 한국어 사용 기 간에서 유의한 차이가 있는지 알아보기 위해 독립표본 $t$-검정(independent sample $t$-test)을 실시하였다. 그 결과, 일본어-한국어 이 중언어 사용자의 한국어 사용기간의 평균은 $26.7(\mathrm{SD}=16.5)$ 개월 로 중국어-한국어 사용자의 한국어 사용기간의 평균 $14.9(\mathrm{SD}=$ $10.7)$ 개월에 비해 유의하게 긴 것으로 나타났다 $(t=2.220, p<.05)$.

실험 대상자는 모두 오른손잡이로 시력 혹은 교정 시력 및 청력 이 정상이고 언어 및 인지발달에 문제가 없었으며 신경학적 손상 및 정신적 병력이 없는 자들로 교육연수가 12 년 이상으로 고등교육 을 마친 자들이었다. 본 연구에 참여한 대상자 정보 및 이중언어 사 용자 집단의 한국어 사용기간의 차이에 대한 독립표본 $t$-검정 결과 는 Table 1 에 제시하였다.

\section{실험 과제}

음운규칙 선정

$\mathrm{Heo}$ (2012) 연구에 따르면 이중언어 사용자들의 발음 오류는 중
국어-한국어 이중언어 사용자의 경우, 연음화에서 가장 적은 오류 를 보이며 비음화와 유음화에 가장 많은 오류를 보인다. 일본어-한 국어 이중언어 사용자의 경우, 다른 언어권 이중언어 사용자와 달 리 격음화에서 매우 높은 오류율을 보인다. 이러한 연구결과에 따 라 중국어-한국어 이중언어 사용자와 일본어-한국어 이중언어 사 용자 모두에게 난이도가 낮은 '연음화, 중국어-한국어 이중언어 사용자에게 중간 난이도이며 일본어-한국어 이중언어 사용자에게 높은 난이도를 보이는 '격음화', 중국어-한국어 이중언어 사용자에 게 높은 난이도이나 일본어-한국어 이중언어 사용자에게 중간 난 이도인 '유음화'로 제한하여 살펴보았다.

\section{음운판단과제}

실험과제는 6 개의 예제 문항과 90 개의 실험문항으로 모두 2 음절 단어로 구성하였다. 피험자는 음운규칙을 적용하여 단어를 읽어 판단해야 했다. 피험자에게 들려준 청각자극은 두 가지 유형으로 1) 음운규칙을 적용하지 않고 자소와 음소를 일치시켜 읽은 오류 형태의 단어 45 개, 2) 음운규칙인 연음화, 격음화, 유음화를 적용하 여 읽은 올바른 형태의 단어 45 개였다.

과제에 사용된 단어는 한국어 학습용 어휘 선정 결과보고서 (Cho, 2003)의 단어목록과 초등학교 교과서에 등장하는 단어 중 음운규칙이 일어나는 단어를 선정하였다. 실험조건 및 자극 예시 는 Table 2에 제시하였다. 과제에 사용된 단어목록은 Appendix 1 에 제시하였다.

\section{청각자극 녹음}

실험에 사용된 모든 청각자극은 쉴드룸에서 디지털 녹음기(Cenix, MVR-W650 Digital Recorder)를 사용하여 아나운서 출신 여 성의 음성으로 녹음하였다. 자극들은 디지털 녹음기에 의해 24비 트, $96 \mathrm{kHz}$ 디지털 신호로 변환되어 저장되었다. 청각자극에 사용 된 단어는 평균 길이가 $941 \mathrm{~ms}$ (범위 781-1,130 ms)였다.

Table 1. Participants' characteristic \& month of using between groups

\begin{tabular}{|c|c|c|c|c|c|c|}
\hline & Gender (N) & & Age (yr) & Month of using Korean & $t$ & Sig. (2-tailed) \\
\hline \multirow[t]{2}{*}{ Korean $(N=15)$} & Male & 2 & $25.8(1.0)$ & & & \\
\hline & Female & 13 & $24.2(4.6)$ & & & \\
\hline \multirow[t]{2}{*}{ Japanese-Korean bilinguals ( $\mathrm{N}=13$ ) } & Male & 0 & - & & & \\
\hline & Female & 13 & $23.4(4.2)$ & $26.7(16.5)$ & & \\
\hline \multirow[t]{2}{*}{ Chinese-Korean bilinguals ( $\mathrm{N}=14$ ) } & Male & 2 & $20.7(2.4)$ & $15(4.2)$ & 2.220 & $0.036^{*}$ \\
\hline & Female & 12 & $24.7(3.5)$ & $15.2(11.6)$ & & \\
\hline
\end{tabular}

Values are presented as mean (SD). ${ }^{*} p<.05$. 
Table 2. Example of stimulus words

\begin{tabular}{|c|c|c|c|c|}
\hline Phonological rules & Example word & Sound stimulus & Example of auditory stimulus & Number of words \\
\hline \multirow[t]{2}{*}{ Liason } & mok yok & Consistent in spelling to sound & mok' yok & 15 \\
\hline & & Inconsistent in spelling to sound & mogyok & 15 \\
\hline \multirow[t]{2}{*}{ Aspiration } & ysk'hal & Consistent in spelling to sound & ynkhal & 15 \\
\hline & & Inconsistent in spelling to sound & $y \Lambda k^{\mathrm{h}} \mathrm{al}$ & 15 \\
\hline \multirow[t]{2}{*}{ Liquidization } & talnim & Consistent in spelling to sound & talnim & 15 \\
\hline & & Inconsistent in spelling to sound & taKKim & 15 \\
\hline
\end{tabular}

\section{연구 절차}

\section{과제 진행 절차}

매 피험자마다 E-Prime 내에서 무작위 배열(random)하여 제시 하였으며 실험 전 예제문항을 제시하여 피험자에게 음운판단과제 에 대해 설명하였다. 예제문항은 음운규칙별 2 개씩 총 6 개의 문항 을 무작위로 제시하였다. 예제문항에서는 피험자의 반응에 대한 정오반응이 제공되었다.

과제 진행 과정은 우선 '+' 표시가 $200 \mathrm{~ms}$ 동안 화면 가운데 나타 나 피험자의 시선을 고정시켰다. 그 후, $200 \mathrm{~ms}$ 동안 빈 화면을 보여 주었다. 그 다음, 시각자극이 $800 \mathrm{~ms}$ 동안 모니터 중앙에 제시되었 다. 시각자극이 사라지면 청각자극과 함께 빈 화면을 최대 $5,000 \mathrm{~ms}$ 동안 제시하였다. 청각자극이 제시된 뒤에 '단어를 올바르게 읽어 자연스럽다'고 생각하면 키보드의 오른쪽 파란 버튼을, '단어를 올 바르게 읽지 않아 부자연스러웠다라고 생각하면 왼쪽 빨간 버튼을 정확하고 빠르게 누르도록 지시하였다. 피험자가 반응을 하면 500 $\mathrm{ms}$ 의 빈 화면을 제시하였다. 그 후, 눈깜빡임을 할 수 있는 1,500 $\mathrm{ms}$ 의 시간을 제시하여 다음 문장을 준비할 수 있도록 하였다.

전체 90 문항의 실험시간은 약 15 분 정도 소요되었고 45 문항마 다 약 1 분간 휴식하였다. 과제가 진행되는 동안 피험자에게 단어를 소리 내어 읽지 않도록 지시하였다. 음운판단과제의 자극제시 순서 는 Figure 1에 제시하였다.

\section{ERP 실험}

쉴드룸(soundproof and electrically shield room)에서 Brain Products사의 BrainAmp와 actiCAP을 사용하여 EEG를 기록하였다. 피험자의 두피에 은/염화은 $(\mathrm{Ag} / \mathrm{AgCI})$ 으로 제작된 전극을 국제 표 준방식인 10-20 system (Jasper, 1958)에 따라 FP1, FP2, F7, F3, F4, F8, FC5, FC1, FC2, FC6, T7, C3, CZ, C4, T8, TP9, CP5, CP1, CP2, $\mathrm{CP} 6, \mathrm{TP} 10, \mathrm{P} 7, \mathrm{P} 3, \mathrm{PZ}, \mathrm{P} 4, \mathrm{P} 8, \mathrm{O} 1, \mathrm{O} 2, \mathrm{VEOG}$ 의 총 29 개를 부착하 였다. 뇌파 신호는 $500 \mathrm{~Hz}$ 로 샘플링되었고, 각 전극의 저항은 $10 \mathrm{k}$ $\Omega$ 이하로 유지하였다. 분석에 포함된 전극은 Anterior left (FP1, F3, FC5, FC1, F7), Anterior right (FP2, F4, FC2, FC6, F8), Posterior-

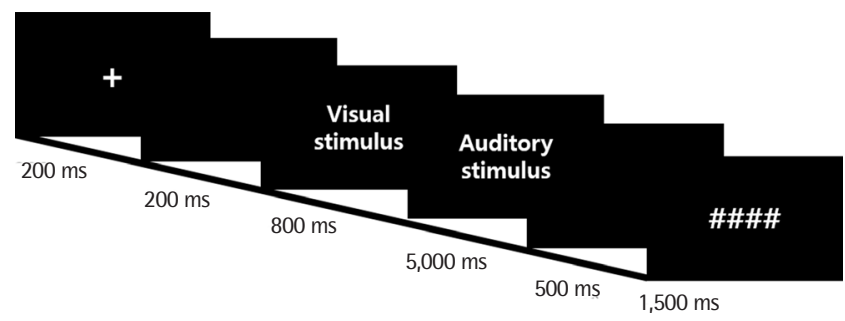

Figure 1. Design of phoneme judgment task.

left (CP5, CP1, P7, P3, O1), Posterior-right (CP2, CP6, P4, P8, O2) 이다(Choi \& $\operatorname{Sim}, 2019)$.

\section{자료 분석}

음운판단과제의 정반응률은 피험자가 정반응한 문항을 전체 문 항수로 나누어 백분율(\%)로 산출하였다.

반응시간은 $1 / 1,000$ 초 $(\mathrm{ms})$ 단위로 측정하여 청각자극이 제시된 뒤 피험자가 판단하여 버튼을 누르기까지의 시간을 측정하였다. 반응시간의 경우 선행연구(Choi \& Sim, 2019)와 동일하게 정반응 을 보인 문항들에 대해서만 분석하였으며 정반응률과 반응시간 모 두 E-prime을 통해 측정되었다.

피험자들이 음운판단과제에서 정반응 보인 $\mathrm{EEG}$ 데이터를 The MathWorks사의 MATLAB R2013b에서 EEGLAB v.12.02.0.5b와 Brain products사의 Brain Vision Analyzer 2.0.3을 이용하여 분석 하였다. 피험자가 정반응한 문항들을 $250 \mathrm{~Hz}$ 에 맞추어 다시 샘플 링 하였다(Luck, 2014, p227). 시각자극 제시 전 $200 \mathrm{~ms}$ 부터 800 $\mathrm{ms}$, 청각자극 제시 전 $200 \mathrm{~ms}$ 부터 $800 \mathrm{~ms}$ 까지 총 $2,000 \mathrm{~ms}$ 동안의 구간(epoch)을 잘랐다. 인지작용에 대한 뇌파를 추출하기 위해 0.1-30 Hz 범위에서 필터링하였고, 눈 깜박임 등으로 인한 기타 잡 음은 제거하였다(Luck, 2014). 이러한 과정을 거친 뒤 남은 시행들 을 조건별로 추출하여 평균을 낸 뒤 ERP 파형을 구하였다.

본 연구의 첫 번째 질문인 한국어 원어민과 이중언어 사용자 간 음운규칙 적용 여부(자소-음소 일치, 자소-음소 불일치)에 따른 단 어재인 시 정반응(\%) 및 반응시간(ms)의 차이가 유의한지 알아보 
기 위하여 이원혼합분산분석(two-way mixed ANOVA)을 실시하 였다. 두 번째 연구 문제인 한국어 원어민과 이중언어 사용자 간 음 운규칙 적용 여부(자소-음소 일치, 자소-음소 불일치)에 따른 단어 재인 시 ERP 평균진폭(mean amplitude, $\mu \mathrm{V}$ )에 유의한 차이가 있 는지 알아보기 위해 사원혼합분산분석(four-way mixed ANOVA) 을 실시하였다. 통계 분석은 SPSS ver. 25 (SPSS Inc., Chicago, IL, USA)를 사용하였다.

\section{연구결과}

\section{정반응률}

음운규칙 적용 여부에 따른 집단 간 정반응률의 차이를 알아보 기 위해 집단, 음운규칙 적용 여부를 독립변인, 음운판단과제의 정 반응률(\%)을 종속변인으로 하는 이원혼합분산분석(two-way mixed ANOVA)을 실시하였다. 음운규칙 적용 여부에 따른 집단별 정반 응률(\%)의 평균 및 표준편차는 Table 3에 제시하였으며, Figure 2에 는 평균과 표준오차를 제시하였다.

집단 간 음운판단과제의 정반응률(\%)은 통계적으로 유의하게 차이가 없는 것으로 나타났다. 반면에 음운규칙 적용 여부에 대한

Table 3. Descriptive statistics of accuracy (\%) on phoneme judgement task for each group

\begin{tabular}{lccc}
\hline & $\begin{array}{c}\text { Korean } \\
(\mathrm{N}=15)\end{array}$ & $\begin{array}{c}\text { Japanese-Korean } \\
\text { bilinguals ( } \mathrm{N}=13)\end{array}$ & $\begin{array}{c}\text { Chinese-Korean } \\
\text { bilinguals ( }=14)\end{array}$ \\
\hline $\begin{array}{l}\text { Inconsistent in spelling } \\
\text { to sound }\end{array}$ & $89.33(8.20)$ & $94.10(7.02)$ & $90.95(8.47)$ \\
$\begin{array}{l}\text { Consistent in spelling to } \\
\text { sound }\end{array}$ & $77.93(13.29)$ & $72.39(10.92)$ & $69.05(9.20)$ \\
\hline
\end{tabular}

Values are presented as mean (SD).
주효과가 유의하게 나타났다 $\left(F_{(1,39)}=66.593, p<.001\right)$. 즉, 음운규 칙을 적용한 조건에서의 정반응률( $91.46 \%)$ 이 음운규칙을 적용하 지 않은 조건에서 정반응률(73.12\%)에 비해 유의하게 높았다. 음운 규칙 적용 여부와 집단 간의 이차상호작용은 통계적으로 유의하지 않았다. 이원혼합분산분석(two-way mixed ANOVA) 결과는 Table 4에 제시하였다.

\section{반응시간}

음운규칙 적용 여부에 따른 집단 간 반응시간의 차이를 알아보 기 위해 집단, 음운규칙 적용 여부를 독립변인, 음운판단과제의 반 응시간(ms)을 종속변인으로 하는 이원혼합분산분석(two-way mixed ANOVA)을 실시하였다. 음운규칙 적용 여부에 따른 집단 별 반응시간의 평균 및 표준편차는 Table 5에 제시하였으며, Figure 3에는 평균과 표준오차를 제시하였다.

집단 간 음운판단과제의 반응시간은 통계적으로 유의하지 않은 것으로 나타났다. 반면에 음운규칙 적용 여부에 대한 주효과가 통 계적으로 유의하였다 $\left(F_{(1,39)}=30.559, p<.001\right)$. 즉, 음운규칙을 적

Table 4. ANOVA results from accuracy on the phoneme judgement task

\begin{tabular}{|c|c|c|c|c|}
\hline Distributed source & $\begin{array}{l}\text { Sum of } \\
\text { squares }\end{array}$ & $\begin{array}{l}\text { Degree of } \\
\text { freedom }\end{array}$ & $\begin{array}{l}\text { Mean } \\
\text { square }\end{array}$ & $F$ \\
\hline \multicolumn{5}{|l|}{ Between factor } \\
\hline Group & 224.517 & 2 & 112.258 & 1.308 \\
\hline Error & $3,347.794$ & 39 & 85.841 & \\
\hline \multicolumn{5}{|l|}{ Within factor } \\
\hline Consistent & $7,039.803$ & 1 & 7,039.803 & $66.593^{* * *}$ \\
\hline Consistent× Group & 521.945 & 2 & 260.972 & 2.469 \\
\hline Error & $4,122.853$ & 39 & 105.714 & \\
\hline
\end{tabular}

${ }^{* * *} p<.001$.

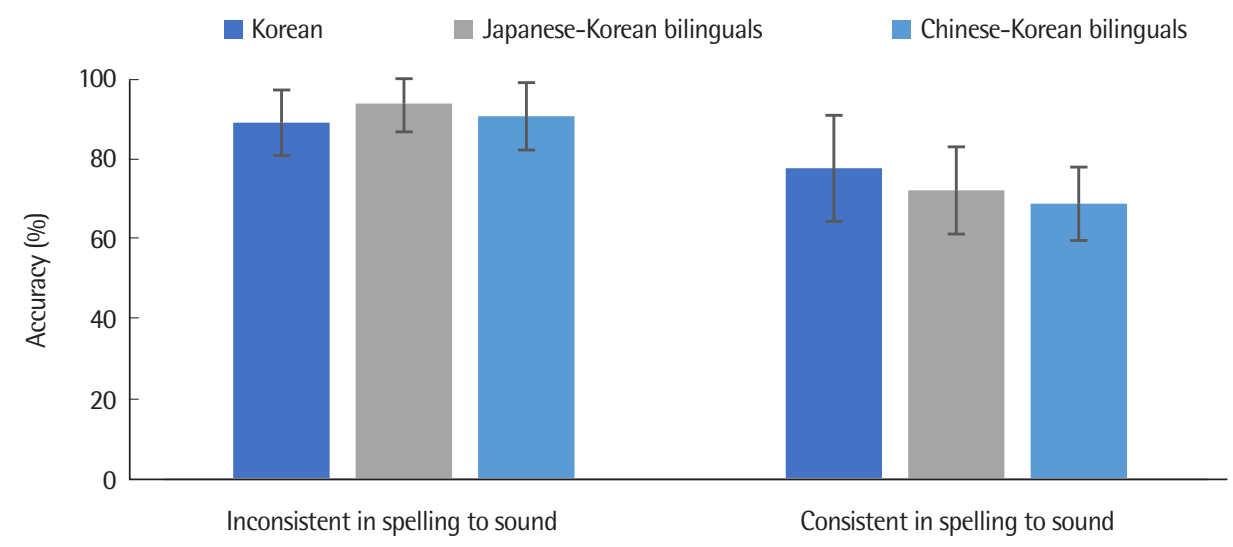

Figure 2. Accuracy on the phoneme judgement task for each group (error bar based on standard error). 
용한 조건에서의 반응시간 $(1,230.84 \mathrm{~ms})$ 이 음운규칙을 적용하지 않은 조건에서의 반응시간 $(1,335.67 \mathrm{~ms})$ 에 비해 유의미하게 더 짧 았다. 음운규칙 적용 여부와 집단의 이차상호작용은 통계적으로 유의하지 않았다. 이원혼합분산분석(two-way mixed ANOVA) 결 과는 Table 6에 제시하였다.

\section{평균진폭(mean amplitude) 크기 분석}

전극 위치별 음운규칙 적용 여부에 따른 ERP 분석의 평균 파형 (grand average wave forms) 결과는 다음 Figures 4-6에 제시하였 다. 다음 그림은 점화자극 제시시점을 기준으로 뇌전위 그래프를 제시한 Kwon과 Lee (2016) 연구와 동일한 방식으로 제시하였다. 집 단 모두 시각자극 제시 이후 $\mathrm{N} 250$ 은 약 $180 \mathrm{~ms}$ 에서 나타났으며, 청 각자극 제시 이후 P200 진폭은 약 $200 \mathrm{~ms}$ 에서 나타나며, N400 진 폭의 시작점은 약 $300 \mathrm{~ms}$ 에서 나타났다.

자극 제시 후 각 구간별 평균 진폭의 차이를 알아보기 위하여 집 단, 음운규칙의 적용 여부(적용, 비적용), 좌우측영역(좌측, 우측 영 역), 전두-후두영역(전두, 후두영역)을 독립변인, 음운판단과제의 평균진폭을 종속변인으로 하는 사원혼합분산분석(four-way mixed ANOVA)을 실시하였다. 그 결과 Tables 7-9에 제시하였으며 주효

Table 5. Descriptive statistics of reaction time (ms) on phoneme judgement task for each group

\begin{tabular}{|c|c|c|c|}
\hline & $\begin{array}{l}\text { Korean } \\
(N=15)\end{array}$ & $\begin{array}{l}\text { Japanese-Korean } \\
\text { bilinguals }(N=13)\end{array}$ & $\begin{array}{l}\text { Chinese-Korean bi- } \\
\text { linguals }(N=14)\end{array}$ \\
\hline $\begin{array}{l}\text { Inconsistent in } \\
\text { spelling to sound }\end{array}$ & $1,145.189(236.750)$ & 1,224.044 (386.914) & 1,323.291 (217.026) \\
\hline $\begin{array}{l}\text { Consistent in spell- } \\
\text { ing to sound }\end{array}$ & $1,238.046(207.873)$ & $1,298.965$ (413.766) & 1,469.996 (254.880) \\
\hline
\end{tabular}

Values are presented as mean (SD).
과 및 상호작용은 분석 구간별로 나누어 기술하는 부분에서 보다 상세하게 통계적 효과가 의미하는 바를 기술하였다.

ERP 결과: N250 (200-350 ms)

음운규칙 적용 유무에 따른 음운판단과제의 집단 간 시각자극 제시 후 200-350 ms 구간의 평균 진폭에서 집단에 대한 주효과가 통계적으로 유의하였다 $\left(F_{(2,39)}=7.283, p<.01\right)$. 따라서 Bonferroni 사후검정을 통하여 주효과에 대한 대응별 비교를 실시하였다. 그 결과, 한국어 원어민과 일본어-한국어 이중언어 사용자, 한국어 원 어민과 중국어-한국어 이중언어 사용자는 유의한 차이를 보였으 나 중국어-한국어 이중언어 사용자와 일본어-한국어 이중언어 사 용자 간에는 유의한 차이를 보이지 않았다. 즉, 시각자극 제시 후 200-350 ms 구간에서 집단 간 평균진폭에 차이를 보였으며 한국어 원어민 $(1.999 \mu \mathrm{V})$ 이 일본어-한국어 이중언어 사용자의 평균진폭 $(5.169 \mu \mathrm{V})$ 과 중국어-한국어 이중언어 사용자의 평균진폭 $(5.538 \mu \mathrm{V})$ 에 비해 음의 방향으로 크게 나타났다.

음운규칙 적용 유무에 대한 주효과가 통계적으로 유의하였다

Table 6. ANOVA results from reaction time on the phoneme judgement task

\begin{tabular}{lrrrr}
\hline Distributed source & $\begin{array}{c}\text { Sum of } \\
\text { squares }\end{array}$ & $\begin{array}{c}\text { Degree of } \\
\text { freedom }\end{array}$ & Mean square & $F$ \\
\hline Between factor & & & & \\
$\quad$ Group & $623,989.195$ & 2 & $311,994.597$ & 1.900 \\
$\quad$ Error & $6,403,847.484$ & 39 & $164,201.218$ & \\
Within factor & & & & \\
Consistent & $229,979.529$ & 1 & $229,979.529$ & $30.559^{* * *}$ \\
Consistent×Group & $19,160.560$ & 2 & $9,580.280$ & 1.273 \\
Error & $293,502.128$ & 39 & $7,525.696$ & \\
\hline
\end{tabular}

${ }^{* * *} p<.001$.

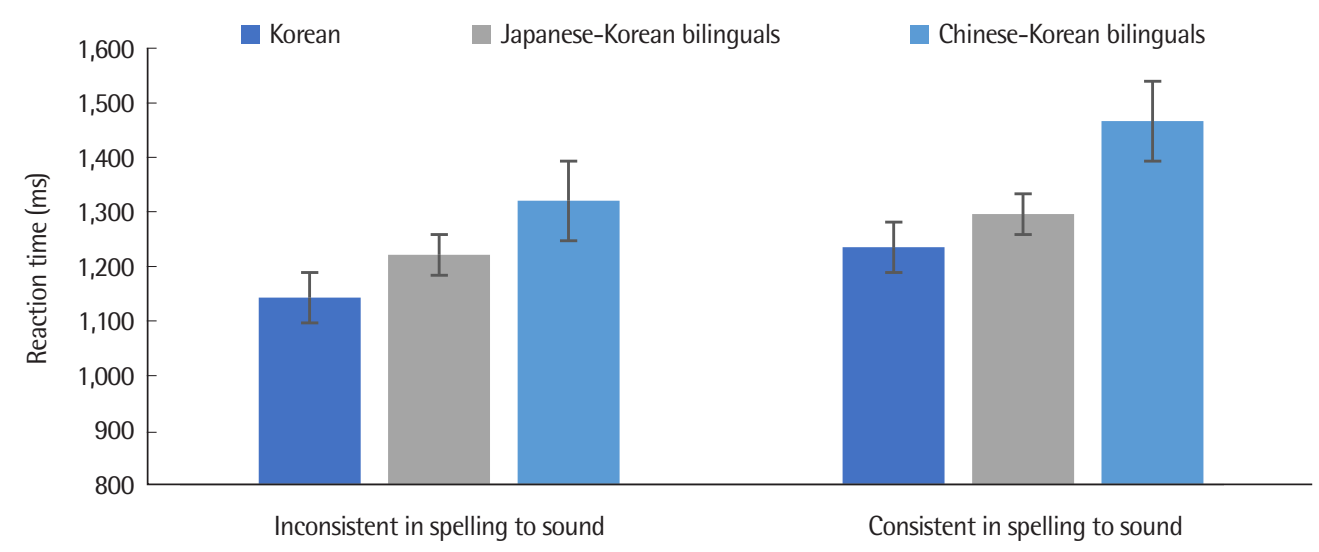

Figure 3. Reaction time on the phoneme judgement task for each group (error bar based on standard error). 
Inconsistent in spelling to sound

- - Consistent in spelling to sound

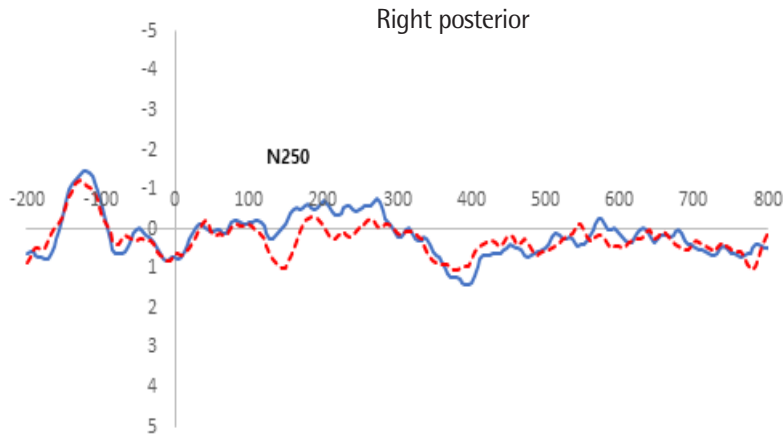

Right posterior
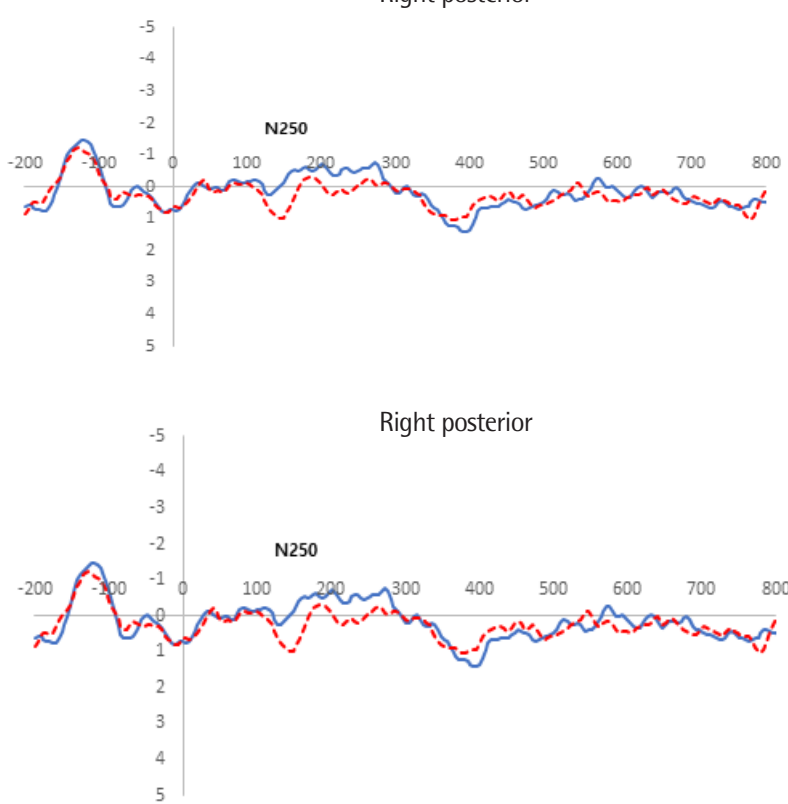

Right posterior
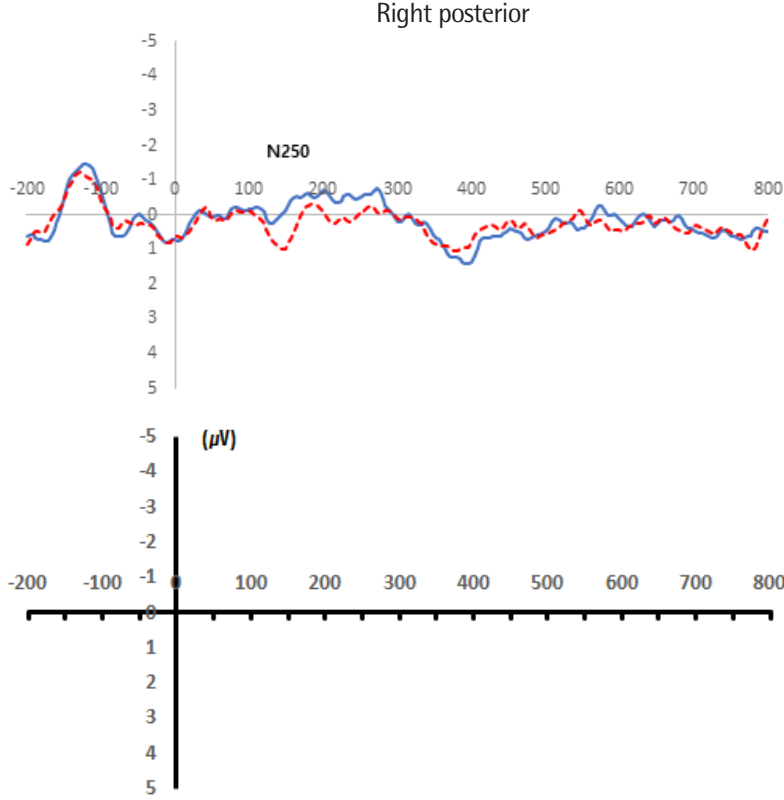
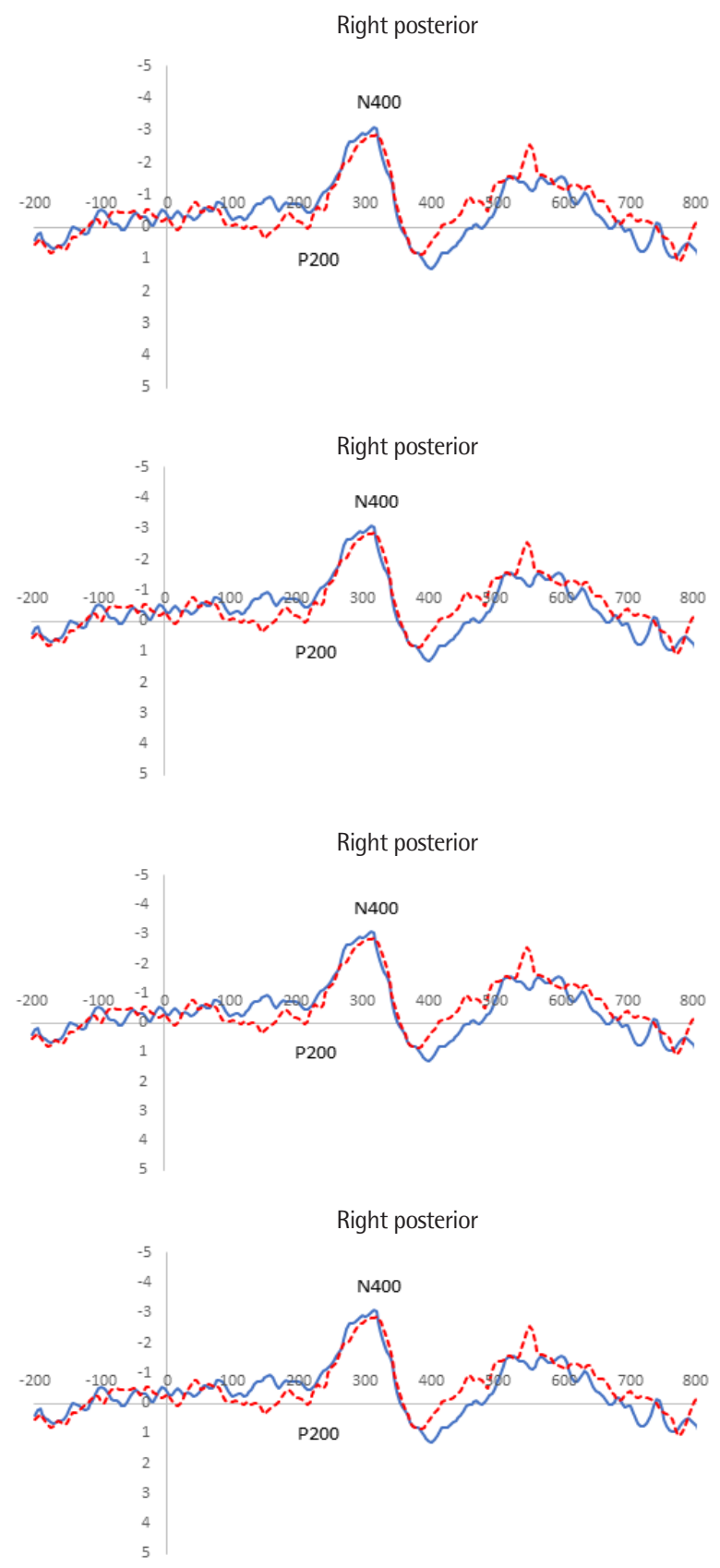

Figure 4. Grand average event-related potential (ERP) waveforms of two conditions at four regions for Korean: word with incorrect pronunciation with unapplied phonological rules (consistent in spelling to sound), word with correct pronunciation with applied phonological rules (inconsistent in spelling to sound). 
- Inconsistent in spelling to sound

- - - Consistent in spelling to sound

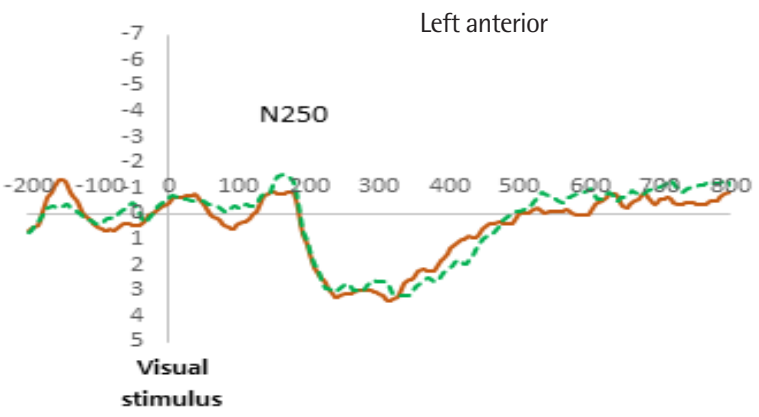

Right anterior

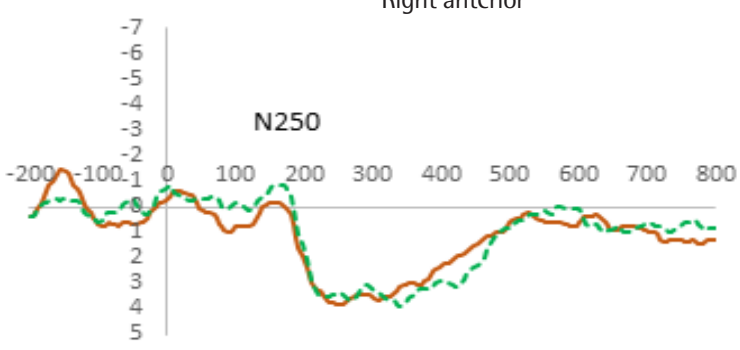

Left posterior

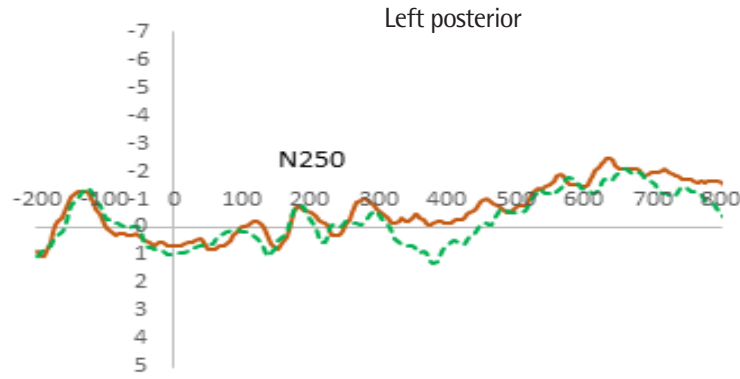

Right posterior
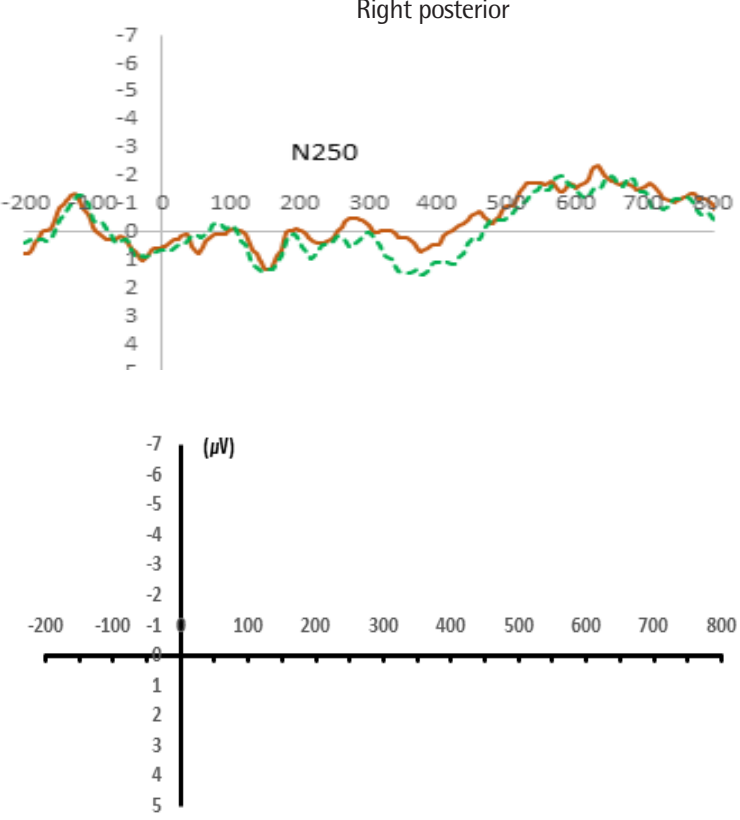

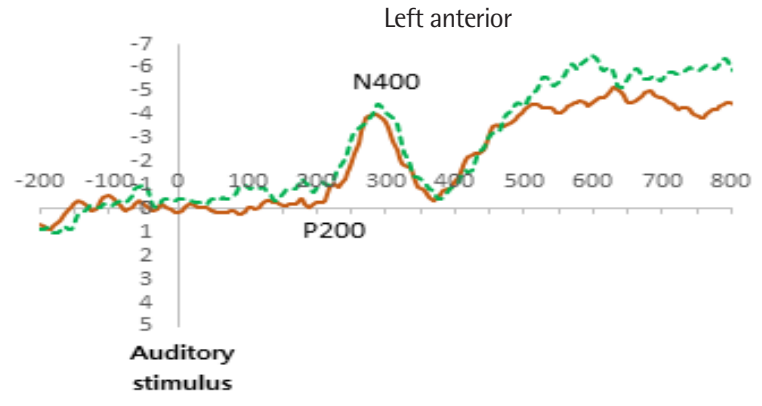

Right anterior

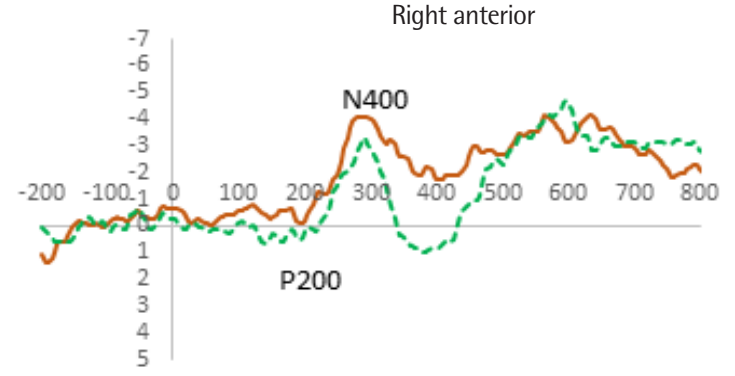

Left posterior
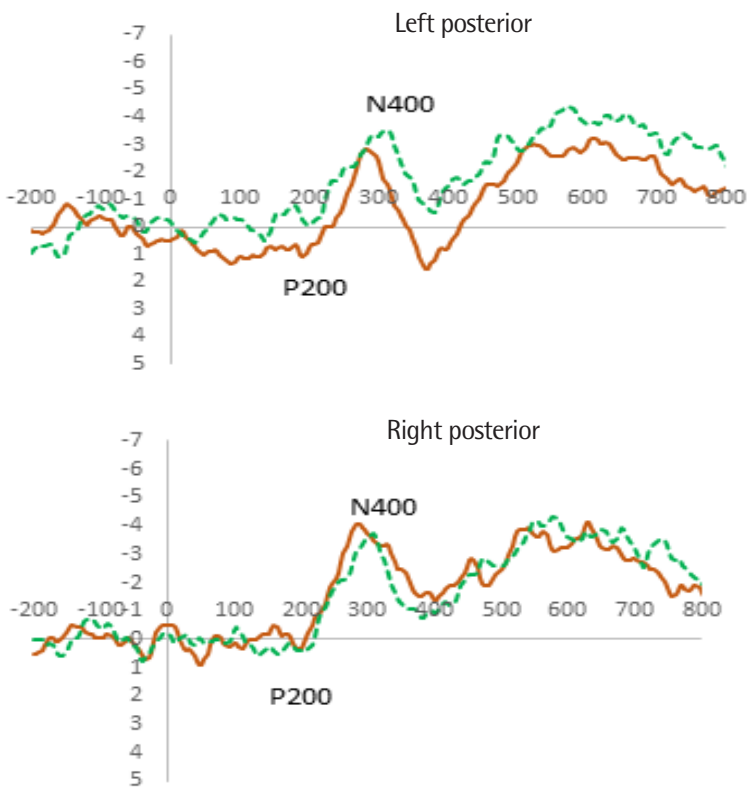

Figure 5. Grand average event-related potential (ERP) waveforms of two conditions at four regions for Japanese-Korean bilinguals: word with incorrect pronunciation with unapplied phonological rules (consistent in spelling to sound), word with correct pronunciation with applied phonological rules (inconsistent in spelling to sound). 
- Inconsistent in spelling to sound --- Consistent in spelling to sound

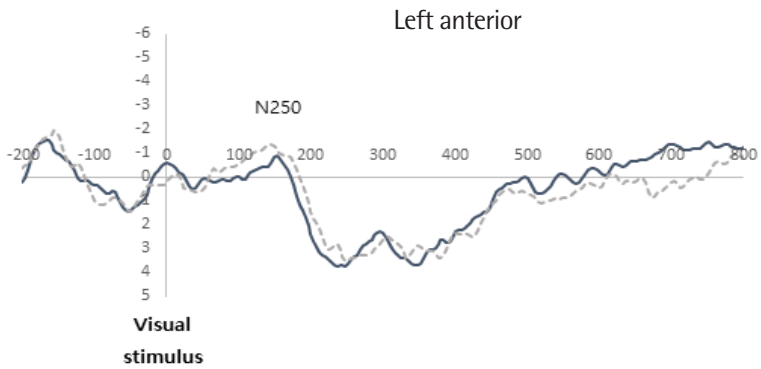

Right anterior

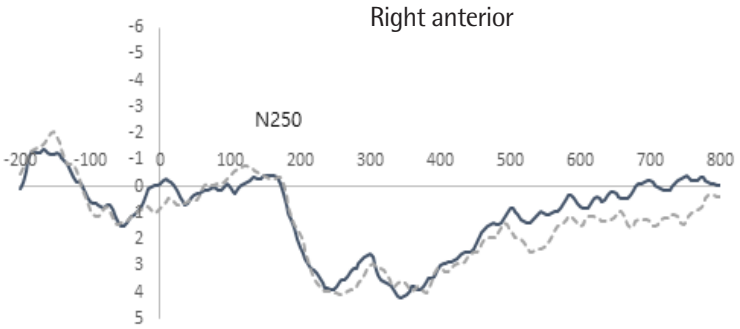

Left posterior

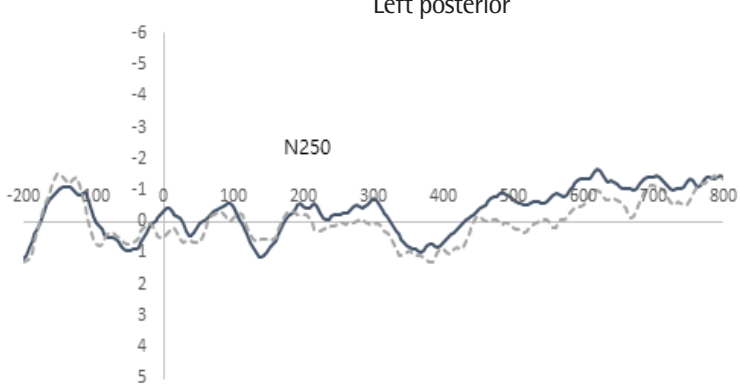

Right posterior
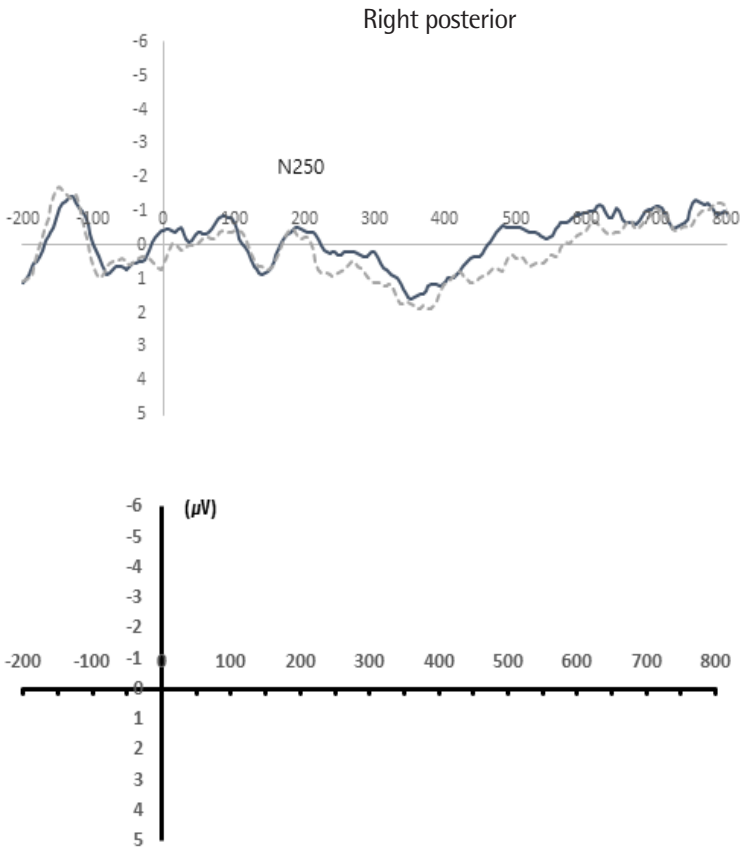

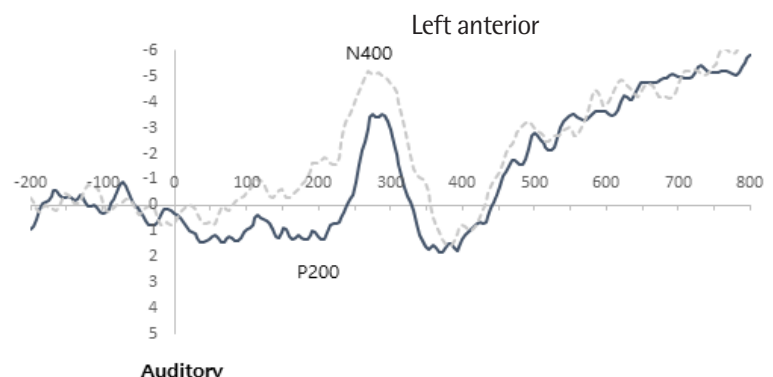

stimulus

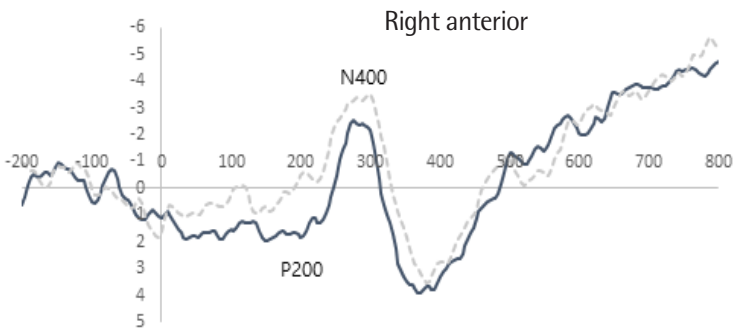

Left posterior

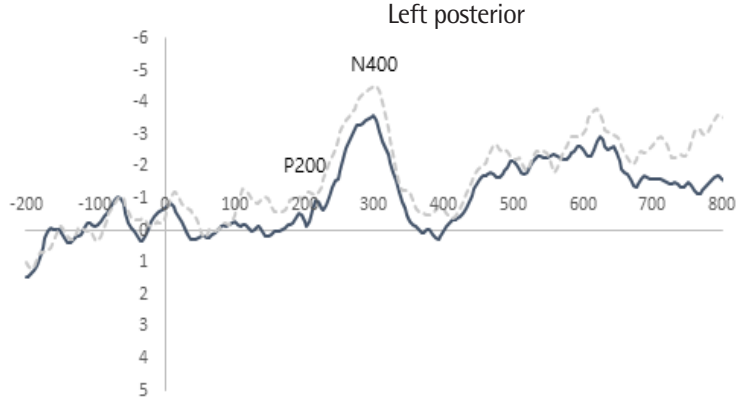

Right posterior

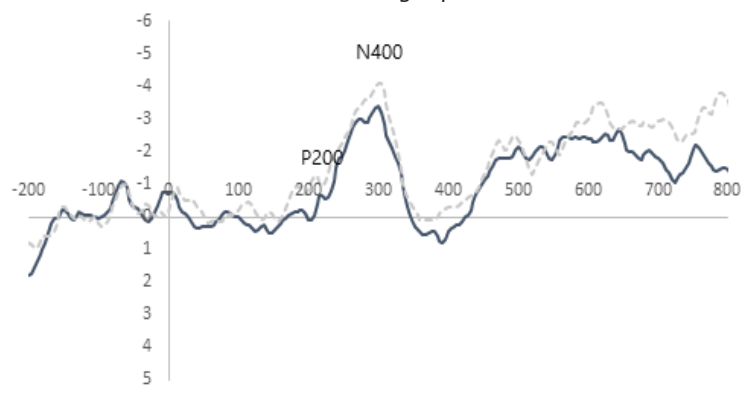

Figure 6. Grand average event-related potential (ERP) waveforms of two conditions at four regions for Chinese-Korean bilinguals: word with incorrect pronunciation with unapplied phonological rules (consistent in spelling to sound), word with correct pronunciation with applied phonological rules (inconsistent in spelling to sound). 
Table 7. Four-way mixed ANOVA results for mean amplitude in 200-350 ms after visual stimulus

\begin{tabular}{|c|c|c|c|c|}
\hline Distributed source & $\begin{array}{l}\text { Sum of } \\
\text { squares }\end{array}$ & $\begin{array}{l}\text { Degree of } \\
\text { freedom }\end{array}$ & $\begin{array}{l}\text { Mean } \\
\text { square }\end{array}$ & $F$ \\
\hline \multicolumn{5}{|l|}{ Between factor } \\
\hline G & 879.174 & 2 & 439.587 & $7.283^{* *}$ \\
\hline Error & 2,354.022 & 39 & 60.36 & \\
\hline \multicolumn{5}{|l|}{ Within factor } \\
\hline Consistent & 58.124 & 1 & 58.124 & $7.584^{* *}$ \\
\hline Consistent $\times \mathrm{G}$ & 31.23 & 2 & 15.615 & 2.037 \\
\hline Error & 298.911 & 39 & 7.664 & \\
\hline L & 1,617.266 & 1 & $1,617.266$ & $131.501^{* * *}$ \\
\hline$L \times G$ & 161.556 & 2 & 80.778 & $6.568^{* *}$ \\
\hline Error & 479.643 & 39 & 12.299 & \\
\hline Ant & 17.746 & 1 & 17.746 & $11.963^{* *}$ \\
\hline Ant $\times G$ & 9.672 & 2 & 4.836 & $3.26^{*}$ \\
\hline Error & 57.853 & 39 & 1.483 & \\
\hline Consistent $\times \mathrm{L}$ & 1.33 & 1 & 1.33 & 0.839 \\
\hline Consistent $\times L \times G$ & 0.586 & 2 & 0.293 & 0.185 \\
\hline Error & 61.814 & 39 & 1.585 & \\
\hline Consistent $\times$ Ant & 0.025 & 1 & 0.025 & 0.042 \\
\hline Consistent $\times$ Ant $\times G$ & 0.504 & 2 & 0.252 & 0.432 \\
\hline Error & 22.759 & 39 & 0.584 & \\
\hline$L \times$ Ant & 17.356 & 1 & 17.356 & $9.006^{* *}$ \\
\hline$L \times A n t \times G$ & 1.729 & 2 & 0.865 & 0.449 \\
\hline Error & 75.159 & 39 & 1.927 & \\
\hline Consistent $\times \mathrm{L} \times$ Ant & 0.262 & 1 & 0.262 & 1.681 \\
\hline Consistent $\times \mathrm{L} \times$ Ant $\times \mathrm{G}$ & 0.097 & 2 & 0.048 & 0.31 \\
\hline Error & 6.079 & 39 & 0.156 & \\
\hline
\end{tabular}

$\mathrm{L}=$ laterality; $\mathrm{Ant}=$ anteriority; $\mathrm{G}=$ group.

${ }^{*} p<.05,{ }^{* *} p<.01,{ }^{* * *} p<.001$.

$\left(F_{(1,39)}=7.584, p<.01\right)$ 즉, 시각자극 제시 후 200-350 ms 구간에서 의 음운규칙이 적용되었을 때 평균진폭 $(3.743 \mu \mathrm{V})$ 이 음운규칙이 적용되지 않았을 때의 평균진폭 $(4.577 \mu \mathrm{V})$ 보다 음의 방향으로 크 게 나타났다.

좌우측영역에 대한 주효과도 통계적으로 유의하였다 $\left(F_{(1,39)}=\right.$ $131.501, p<.001)$. 즉, 시각자극 제시 후 200-350 ms 구간에서 좌측 영역의 평균 진폭 $(3.921 \mu \mathrm{V})$ 이 우측영역의 평균진폭 $(4.399 \mu \mathrm{V})$ 보다 음의 방향으로 유의하게 큰 것으로 나타났다. 좌우측영역 및 집단 간 이차상호작용이 통계적으로 유의하였다 $\left(F_{(2,39)}=6.568, p<.01\right)$. 사 후검정을 실시한 결과, 한국어 원어민과 이중언어 사용자 간 유의 한 차이를 보였지만 이중언어 사용자 간에는 유의한 차이가 나타 나지 않았다.

전두-후두영역에 대한 주효과도 통계적으로 유의하였다 $\left(F_{(1,39)}=\right.$ $11.963, p<.01)$. 즉, 후두영역에서의 평균진폭 $(1.999 \mu \mathrm{V})$ 이 전두영역 에서의 평균진폭 $(6.321 \mu \mathrm{V})$ 에 비해 음의 방향으로 유의하게 컸다.
Table 8. Four-way mixed ANOVA results for mean amplitude in 150-300 ms after auditory stimulus

\begin{tabular}{|c|c|c|c|c|}
\hline Distributed source & $\begin{array}{l}\text { Sum of } \\
\text { squares }\end{array}$ & $\begin{array}{l}\text { Degree of } \\
\text { freedom }\end{array}$ & $\begin{array}{l}\text { Mean } \\
\text { square }\end{array}$ & $F$ \\
\hline \multicolumn{5}{|l|}{ Between factor } \\
\hline G & 26.751 & 2 & 13.375 & 0.325 \\
\hline Error & 1,604.287 & 39 & 41.136 & 41.136 \\
\hline \multicolumn{5}{|l|}{ Within factor } \\
\hline Consistent & 31.552 & 1 & 31.552 & 3.016 \\
\hline Consistent $\times \mathrm{G}$ & 42.111 & 2 & 21.055 & 2.013 \\
\hline Error & 407.994 & 39 & 10.461 & \\
\hline Ant & 21.137 & 1 & 21.137 & 3.440 \\
\hline Ant $\times G$ & 13.246 & 2 & 6.623 & 1.078 \\
\hline Error & 239.633 & 39 & 6.144 & \\
\hline L & 35.470 & 1 & 35.470 & $15.260^{* * *}$ \\
\hline$L \times G$ & 0.722 & 2 & 0.361 & 0.155 \\
\hline Error & 90.651 & 39 & 2.324 & \\
\hline Consistent $\times$ Ant & 5.178 & 1 & 5.178 & 2.467 \\
\hline Consistent $\times$ Ant $\times G$ & 5.901 & 2 & 2.951 & 1.406 \\
\hline Error & 81.850 & 39 & 2.099 & \\
\hline Consistent $\times \mathrm{L}$ & 0.930 & 1 & 0.930 & 2.280 \\
\hline Consistent $\times L \times G$ & 1.220 & 2 & 0.610 & 1.495 \\
\hline Error & 15.913 & 39 & 0.408 & \\
\hline Ant $\times L$ & 13.578 & 1 & 13.578 & $17.320^{* * *}$ \\
\hline Ant $\times L \times G$ & 0.356 & 2 & 0.178 & 0.227 \\
\hline Error & 30.573 & 39 & 0.784 & \\
\hline Consistent $\times$ Ant $\times \mathrm{L}$ & 0.004 & 1 & 0.004 & 0.015 \\
\hline Consistent $\times$ Ant $\times L \times G$ & 0.091 & 2 & 0.046 & 0.163 \\
\hline Error & 10.933 & 39 & 0.280 & \\
\hline
\end{tabular}

전두-후두영역 및 집단 간 이차상호작용이 통계적으로 유의하였 다 $\left(F_{(2,39)}=3.26, p<.05\right)$. 사후검정 결과, 한국어 원어민과 일본어한국어 이중언어 사용자, 한국어 원어민과 중국어-한국어 이중언 어 사용자간의 유의한 차이가 나타났다.

좌우측영역 및 전두-후두영역 간 이차상호작용이 통계적으로 유의하였다 $\left(F_{(1,39)}=9.006, p<.01\right)$. 즉, 좌측영역에서 전두-후두영 역 진폭 차이가 우측 영역에서의 전두-후두영역 진폭 차이에 비해 큰 것으로 나타났다. 분산분석 결과는 Table 7에 제시하였다.

\section{ERP 결과: P200 (150-300 ms)}

음운규칙 적용 유무에 따른 음운판단과제의 집단 간 청각자극 제시 후 150-300 ms 구간의 평균 진폭에서 집단에 대한 주효과는 통계적으로 유의한 차이를 보이지 않았다. 음운규칙 적용 유무에 대한 주효과도 통계적으로 유의한 차이를 보이지 않았다.

좌우측영역에 대한 주효과가 통계적으로 유의하였다 $\left(F_{(1,39)}=\right.$ 
Table 9. Four-way mixed ANOVA results for mean amplitude in 300-500 ms after auditory stimulus

\begin{tabular}{|c|c|c|c|c|}
\hline Distributed source & $\begin{array}{l}\text { Sum of } \\
\text { squares }\end{array}$ & $\begin{array}{l}\text { Degree of } \\
\text { freedom }\end{array}$ & $\begin{array}{l}\text { Mean } \\
\text { square }\end{array}$ & $F$ \\
\hline \multicolumn{5}{|l|}{ Between factor } \\
\hline G & 211.635 & 2 & 105.817 & 1.533 \\
\hline Error & $2,691.664$ & 39 & 69.017 & \\
\hline \multicolumn{5}{|l|}{ Within factor } \\
\hline Consistent & 34.721 & 1 & 34.721 & $4.960^{*}$ \\
\hline Consistent $\times \mathrm{G}$ & 6.239 & 2 & 3.120 & 0.446 \\
\hline Error & 272.987 & 39 & 7.000 & \\
\hline Ant & 210.391 & 1 & 210.391 & $12.827^{* *}$ \\
\hline Ant $\times G$ & 38.580 & 2 & 19.290 & 1.176 \\
\hline Error & 639.711 & 39 & 16.403 & \\
\hline L & 102.674 & 1 & 102.674 & $39.645^{* * *}$ \\
\hline$L \times G$ & 0.526 & 2 & 0.263 & 0.102 \\
\hline Error & 101.003 & 39 & 2.590 & \\
\hline Consistent $\times$ Ant & 0.797 & 1 & 0.797 & 0.479 \\
\hline Consistent $\times$ Ant $\times G$ & 1.286 & 2 & 0.643 & 0.386 \\
\hline Error & 64.910 & 39 & 1.664 & \\
\hline Consistent $\times \mathrm{L}$ & 0.078 & 1 & 0.078 & 0.168 \\
\hline Consistent $\times L \times G$ & 0.735 & 2 & 0.368 & 0.792 \\
\hline Error & 18.098 & 39 & 0.464 & \\
\hline Ant $\times \mathrm{L}$ & 34.398 & 1 & 34.398 & $22.962^{* * *}$ \\
\hline Ant $\times L \times G$ & 2.048 & 2 & 1.024 & 0.684 \\
\hline Error & 58.423 & 39 & 1.498 & \\
\hline Consistent $\times$ Ant $\times \mathrm{L}$ & 0.004 & 1 & 0.004 & 0.007 \\
\hline Consistent $\times$ Ant $\times L \times G$ & 1.108 & 2 & 0.554 & 0.996 \\
\hline Error & 21.703 & 39 & 0.556 & \\
\hline
\end{tabular}

$\mathrm{L}=$ laterality; Ant= anteriority; $\mathrm{G}=$ group.

${ }^{*} p<.05,{ }^{* *} p<.01,{ }^{* * *} p<.001$.

$15.260, p<.001)$. 즉, 청각자극 제시 후 $150-300 \mathrm{~ms}$ 구간에서 우측 영역의 평균 진폭 $(-0.593 \mu \mathrm{V})$ 이 좌측영역의 평균 진폭 $(-1.239 \mu \mathrm{V})$ 보 다 유의하게 큰 것으로 나타났다. 좌우측영역 및 전두-후두영역 간 이차상호작용이 통계적으로 유의미하였다 $\left(F_{(1,39)}=17.320, p<.001\right)$. 즉, 우측영역에서 전두-후두영역의 진폭 차이가 좌측영역에서의 전두-후두영역의 진폭 차이에 비해 큰 것으로 나타났다. 분산분석 결과는 Table 8에 제시하였다.

\section{ERP 결과: N400 (300-500 ms)}

음운규칙 적용 유무에 따른 음운판단과제의 집단 간 청각자극 제시 후 300-500 ms 구간의 평균진폭에서 집단에 대한 주효과는 통계적으로 유의한 차이를 보이지 않았다.

좌우측영역 및 전두-후두영역에서의 음운규칙 적용 여부에 따 른 음운판단과제의 집단 간 청각자극 제시 후 300-500 ms 구간의 평균진폭에서 음운규칙 적용 유무에 대한 주효과가 통계적으로 유

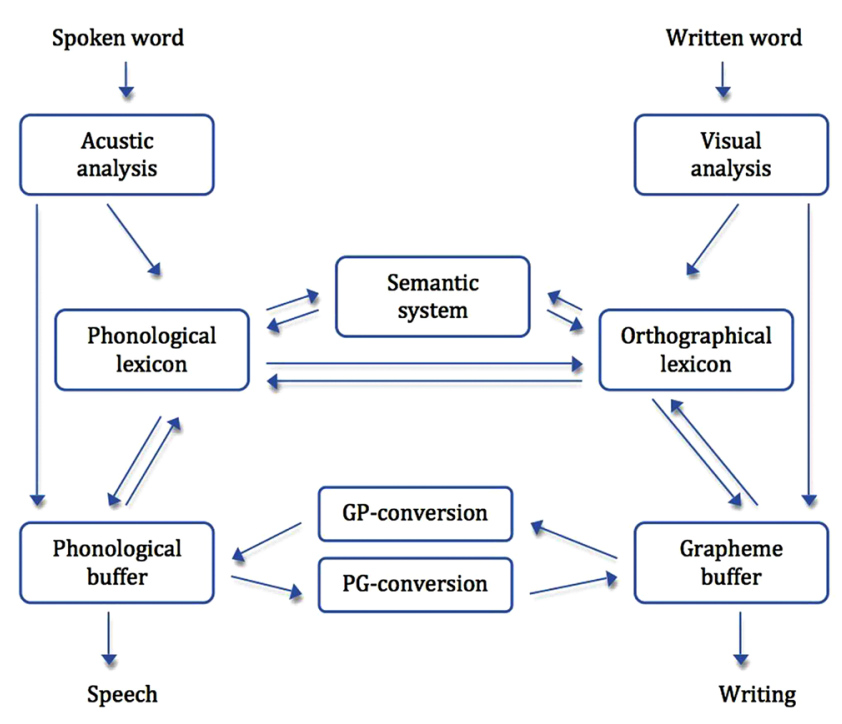

Figure 7. Dual route model (Döhla and Heim, 2016).

의하였다 $\left(F_{(1,39)}=4.960, p<.05\right)$. 즉, 음운규칙을 적용했을 때의 평 균진폭(-0.111 $\mu \mathrm{V})$ 이 음운규칙을 적용하지 않았을 때의 평균진폭 $(0.750 \mu \mathrm{V})$ 에 비해 음의 방향으로 유의하게 크게 나타났다.

전두-후두영역에 대한 주효과도 통계적으로 유의하였다 $\left(F_{(1,39)}=\right.$ $12.827, p<.01)$. 즉, 후두영역의 평균진폭 $(-1.243 \mu \mathrm{V})$ 이 전두영역의 평균진폭 $(0.382 \mu \mathrm{V})$ 에 비해 음의 방향으로 유의하게 큰 것으로 나타 났다. 좌우측영역에 대한 주효과도 통계적으로 유의하였다 $\left(F_{(1,39)}=\right.$ $39.645, p<.001)$. 즉, 좌측영역의 평균진폭 $(-.0986 \mu \mathrm{V})$ 이 우측영역 의 평균진폭 $(0.125 \mu \mathrm{V})$ 에 비해 음의 방향으로 유의하게 큰 것으로 나타났다.

좌우측영역 및 전두-후두영역 간 이차상호작용이 통계적으로 유 의미하였다 $\left(F_{(1,39)}=22.962, p<.001\right)$. 즉, 우측영역에서 전후-후두 영 역의 진폭차이가 좌측영역에서의 전두-후두영역의 진폭차이에 비 해 큰 것으로 나타났다. 분산분석 결과는 Table 9에 제시하였다.

\section{논의 및 결론}

본 연구의 목적은 한국어 원어민과 일본어-한국어 이중언어 사 용자, 중국어-한국어 이중언어 사용자 간의 음운규칙 적용 여부에 따라 집단 간 음운판단과제의 정반응률 및 반응속도, ERP 성분의 평균 진폭(mean amplitude) 크기의 차이를 알아보는 것이다.

집단 간 음운판단과제의 정반응률과 반응시간에 있어 차이를 보이지만 통계적으로 유의하지 않았다. 한국어 원어민의 경우에는 한국어를 모국어로 습득하기 때문에 말소리를 듣고 말하기부터 배 우기 시작한다. 읽기를 배우는 과정에서도 자연스럽게 일상생활에 
노출되어 습득한다. 반면에, 이중언어 사용자의 경우에는 읽기와 말하기를 거의 동시에 배우게 되며 음운규칙을 학습하고 의식하여 적용한다. 이러한 사실을 미루어보면, 한국어 원어민과 이중언어 사용자는 음운규칙을 습득한 과정은 다르지만, 음운규칙에 대한 음운지식이 집단 모두 형성되어 있기에 정반응률과 반응시간에 집 단 간 유의한 차이를 보이지 않았다고 볼 수 있다.

음운규칙 적용 유무에 따라 집단 간 정반응률과 반응시간 모두 유의한 차이를 보였다. 한국어 원어민, 이중언어 사용자 집단 모두 음운규칙을 적용한 경우(예, 시각자극 '목욕', 청각자극 '[모곡]')의 정반응률이 음운규칙을 적용하지 않은 경우(예, 시각자극 '목욕', 청각자극 '[목욕]')의 정반응률 보다 높았다. 또한 반응시간도 음운 규칙을 적용한 경우가 음운규칙을 적용하지 않은 경우보다 유의하 게 빨랐다. Figure 7에서 제시한 Döhla와 Heim (2016)의 읽기와 쓰 기의 이중경로 모델에 따르면, 시각자극이 제시되었을 때에는 시각 적 분석(visual analysis)-자소 완충기(grapheme buffer)-자소 음소 변환(grapheme phoneme conversion, GPC)-음운완충기(phonological buffer)를 거친다. 그 다음 제시되는 청각자극을 재인할 때 에는 청각적 분석(acoustic analysis)-음운완충기(phonological buffer)의 경로를 거친다. 즉, 시각자극을 제시하였을 때와 청각자 극을 제시하였을 때의 처리과정은 동일하지 않기 때문에, 피험자 는 각각의 과정을 통해 처리된 결과를 비교하여 정오판단을 해야 한다. 따라서 본 연구에서 피험자는 시각자극(예, 목욕)을 통해 처 리한 음운정보(예, [모고]ᄀ])와 청각자극을 통해 처리한 음운정보(예, 목욕)를 대조하여 판단해야 하기 때문에 긴 시간이 필요했다고 볼 수 있다.

$\mathrm{ERP}$ 성분에 대한 시간대별 결과를 살펴보면, 시각자극 제시 후 200-350 ms 구간에서 나타난 N250 성분은 집단 간 평균진폭에서 차이를 보였다. N250은 하위-어휘 처리 수준의 자소-음소 대응처 리를 반영한다(Grainger \& Holcomb, 2009). 선행연구(Hoshino et al., 2010)와 동일하게 점화자극과 목표자극이 모두 모국어인 한국 어 원어민은 N250 성분이 크게 활성화되었으나, 한국어를 제 2 외국 어로 사용하는 이중언어 사용자는 N250 성분이 작게 나타났다. 이 는 음운을 처리하는 과정에서 이중언어 사용자는 한국어를 모국 어로 습득한 경우보다 음운규칙 적용이 활발하게 이루어지지 않 아 N250 성분이 작게 나타났다고 해석할 수 있다. 또한 이중언어 사 용자에게 제시된 단어가 무의미 단어라고 보았을 때, 시각자극 제 시 후 의미 단어에 비해 무의미 단어에서 N250 성분의 활성화를 보 고한 Choi와 $\operatorname{Sim}$ (2019) 연구와도 동일하다. N250 성분은 음운규 칙 적용 여부에 따라서도 평균 진폭에 차이를 보였다. 점화자극이 목표자극과 관련 없는 경우 N250 성분이 크게 활성화된다는 선행
연구(Kwon et al., 2015; Grainger \& Holcomb, 2006)와 동일한 결과 로, 음운규칙을 적용하여 자소와 음소가 일치하지 않게 제시한 음 운불일치 조건이 음운규칙을 적용하지 않고 표기 그대로 자소와 음소를 일치시켜 제시한 조건보다 크게 나타났다. 자소와 음소를 일치하지 않게 제시한 음운불일치 조건에서 N250 성분의 활성화 는 한국어가 자소-음소 대응이 규칙적임에도 불구하고 자소-음소 처리 과정이 존재한다고 해석된다. N250 성분은 집단 간 좌우측영 역, 집단 간 전두-후두영역의 활성화차이를 보였다. 좌측 하전두이 랑(left inferior frontal gyrus)은 읽기에서 자소-음소 대응 처리와 밀접한 관련성이 있는 것으로 알려져 있다(Burton, 2001; Joubert et al., 2004; Kwon \& Lee, 2016). 시각자극 제시 이후 하전두이랑에서 자소-음소 대응 처리가 이루어져 활성화에 차이를 보인 것으로 해 석된다.

청각자극 제시 후 150-300 ms 구간에서 나타나는 P200 성분은 음운규칙 적용 여부에 따라 차이를 보이지 않았다. $\mathrm{P} 200$ 은 의미처 리 이전에 나타나는 음운처리 관련 성분으로 알려져 있다(Liu et al., 2003; Kong et al., 2010). 이 결과는 시각자극만 사용하여 P200 성분을 살펴본 선행연구(Kwon, Lee, \& Nam, 2011)와는 달리, 시각 자극을 제시하였을 때 초기 자소-음소 처리가 이루어졌기 때문에 다음에 제시되는 청각자극에서는 성분이 관찰되지 않았다고 볼 수있다.

의미처리 시 활성화를 보이는 N400(청각자극 제시 후 300-500 $\mathrm{ms})$ 은 음운규칙 적용 유무에 따른 차이를 보였다. 음운규칙을 적 용한 경우 더 큰 진폭을 보인 결과는 의미가 처리되었다고 해석할 수 있다(Kwon \& Lee, 2016). Hoshino 등(2010)에 의하면 점화자극 과 목표자극을 의미적으로 분류하는 과제를 사용하여 L1과 L2의 처리과정을 보았을 때, $\mathrm{L} 2$ 에 비해 $\mathrm{L} 1$ 을 처리하는 과정에서 $\mathrm{N} 400$ 이 크게 나타난다. 이러한 결과와 동일하게 한국어 원어민이 이중언어 사용자보다 더 큰 $\mathrm{N} 400$ 을 보일 것이라고 판단하였다. 그러나 본 연 구에서는 집단 간 N400 성분에 차이를 보이지 않았다. 이러한 결과 는 Kim (2010) 연구에서 한국어-영어 이중언어 사용자가 L2인 영 어를 처리할 때 $\mathrm{N} 400$ 효과를 보이지 않은 결과와 일치한다. 선행연 구에서는 모국어 자극에서만 N400이 활성화되어 L2를 사용하여 대답하는 것이 영어 모국어 화자의 민감도에 미치지 못함을 시사했 다. 또한 모국어에서는 학습한 언어를 전환하지 않고 동일한 언어 내에서 의미적 적절성 여부를 신속히 판단하고 결정할 수 있지만, $\mathrm{L} 2$ 전환 시에는 모국어의 간섭으로 인해 N400 성분이 정점을 보이 지 않았다고 해석하였다. 따라서 본 연구에서 집단 간 의미처리 성 분인 N400의 차이를 보이지 않은 이유는 이중언어 사용자 집단이 한국어 원어민에 비해 의미를 처리하는데 민감도가 낮으며 모국어 
의 간섭으로 인해 보인 차이라고 볼 수 있다.

집단 사이 정반응률과 반응시간에 있어 유의한차이를 보이지 않 은 결과는 한국어 원어민과 이중언어 사용자 집단의 음운지식 습 득 과정이 다르더라도 형성되어 있는 단어재인 능력에 차이를 보이 지 않음을 알 수 있었다. ERP로 살펴본 단어재인 처리 과정에서도 $\mathrm{N} 250$ 과 N400 성분에 차이를 볼 수 있었다. 이러한 결과는 한국어 원어민과 이중언어 사용자 집단 모두 초기에 자소-음소 전환이 필 수적으로 이루어진다고 볼 수 있다. 집단 간 N250 성분에 차이를 보 인 결과는 제 2 외국어로 한국어를 사용하는 이중언어 사용자는 한 국어를 모국어로 습득한 경우보다 쓰여진 글자를 보고 처리하는 초 기 과정에서 자소-음소 전환의 어려움을 보인다고 할 수 있다. 종합 해보면 이중언어 사용자 일지라도 한국어에 노출되는 시간을 늘리 고, 음운규칙이 적용되는 단어를 많이 접한다면 한국어 원어민과 동일한 자소-음소 전환 처리를 할 수 있다는 가능성을 제시한다.

본 연구의 제한점 및 후속연구를 위한 제언은 다음과 같다. 첫째, 실험에 사용된 과제는 이중언어 사용자를 대상으로 하여 시각자 극을 제시하는 시간이 길었으며, 청각자극이 제시된 뒤 자소-음소 전환을 순수하게 보여주는 파형이라고 판단하기에는 무리가 있다. 둘째, 한국어의 경우 음운규칙을 적용하지 않고도 읽을 수 있기에 피험자들의 정오판단을 분명하게 하기 위해 문장 내 단어를 포함시 키거나 시각자극을 제시한 뒤 읽도록 하는 등 피험자의 판단 과정 을 단순화시킬 필요가 있다. 셋째, 이중언어 사용자 집단을 선정할 때 한국어 능력을 초급 이상이라는 최소한의 제한을 두고 실험을 진행하였으나 상대적으로 일본어-한국어 이중언어 사용자 집단은 평균 26.7 개월, 중국어-한국어 사용자 집단은 평균 14.9 개월의 학 습기간을 보여 학습기간에 따른 한국어 능력의 차이가 결과에 영 향을 주었을 가능성을 배제하기 어렵다. 향후 연구에서는 집단의 선정 기준을 명확히 통제하여 진행할 필요가 있다.

본 연구는 한국어 특수성을 고려하여 시각자극과 청각자극을 통해 단어를 재인하여 음운규칙 적용 여부에 따라 한국어 원어민 과 이중언어 사용자의 처리과정과 ERP 성분의 차이를 알아보고자 한 연구로서, 한국어를 외국어로 습득하는 다문화 가정의 부모, 한 국어를 배우는 과정인 이중언어 아동들에게 한국어 음운지식을 형성하기 위해 습득 과정보다 장시간 한국어의 노출과 음운규칙 적용의 기회를 제공할 필요하다는 점을 시사한다.

\section{REFERENCES}

Burton, M. W. (2001). The role of Inferior frontal cortex in phonological processing. Cognitive Science, 25(5), 695-709.
Cho, N. H. (2003). Report on essential Korean vocabulary for foreigners. Seoul: The National Academy of the Korean Language.

Choi, S. J. (2017). The phonological activation in Korean word and non-word recognition: evidence from event-related potential (Master's thesis). Ewha Womans University, Seoul, Korea.

Choi, S. J., \& Sim, H. S. (2019). Grapheme-phoneme conversion in Korean word recognition: evidence from event-related potentials. Communication Science \& Disorders, 24(3), 647-655.

Döhla, D., \& Heim, S. (2016). Developmental dyslexia and dysgraphia: what can we learn from the one about the other?. Frontiers in Psychology, 6, 2045.

Fengyang, M., Peiyao, C., Taomei. G., \& Judith F. K. (2017). When late second language learners access the meaning of L2 words: using ERPs to investigate the role of the L1 translation equivalent. Journal of neurolinguistics, 41, 50-69.

Grainger, J., \& Holcomb, P. J. (2009). Watching the word go by: on the timecourse of component processes in visual word recognition. Language and linguistics compass, 3(1), 128-156.

Grainger, J., Kiyonaga, K., \& Holcomb, P. J. (2006). The time course of orthographic and phonological code activation. Psychological Science, 17(12), 1021-1026.

Heo, Y. (2012). A phonological analysis on pronunciation errors of Korean language learners - focusing on phonological processes. The Koreanology insistence, 46, 201-232.

Hoshino, N., Midgley, K. J., Holcomb, P. J., \& Grainger, J. (2010). An ERP investigation of masked cross-script translation priming. Brain Research, 1344, 159-172.

Jasper, H. H. (1958). The ten-twenty electrode system of the international federation. Electroencephalography and Clinical Neurophysiology, 10, 370375.

Joubert, S., Beauregard, M., Walter, N., Bourgouin, P., Beaudoin, G.,leroux, J., Karama, S., \& Lecours, A. (2004). Neural correlates of lexical and sublexical processes in reading. Brain and language, 89(1), 9-20.

Kim, C. M. (2010). Differential effect for neural activation processes according to the proficiency level of code switching: an ERP study. Phonetics and Speech Sciences, 2(4), 3-10.

Kim, T. K., Baek, G. M. (2015). A study on Korean phonemic alternation by Korean-learning Chinese speakers. Urimalgeul: The Korean Language and Literature, 64, 117-151.

Kong, L., Zhang, J. X., Kang, C., Du, Y., Zhang, B., \& Wang, S. (2010). P200 and phonological processing in Chinese word recognition. Neuroscience 
Letters, 473(1), 37-41.

Kwon, Y. A., \& Lee, Y. H. (2016). Temporal locus of the Influence of phonological Information during Korean visual word recognition: event-related potential evidences of homophone. Journals of Linguistic Science, 76, 1-21.

Kwon, Y. A., Nam, Y. E., \& Lee, Y. H. (2015). The effect of the phonological Information in the Korean visual word recognition: an event related potential study. The Journal of Linguistics Science, 75, 23-42.

Kwon, Y., Choi, S., \& Lee, Y. (2016). Early use of orthographic information in spoken word recognition: Event-related potential evidence from the Korean language. Psychophysiology, 53(4), 544-552.

Kwon, Y., Lee, Y., \& Nam, K. (2011). The different P200 effects of phonological and orthographic syllable frequency in visual word recognition in Korean. Neuroscience Letters, 501(2), 117-121.
Lim, Y. J., \& Kim, Y. T. (2008). A comparison of the ability of 2nd graders and 5 th graders to apply phonological rules in reading exercises. Korean Journal of Communication Disorders, 13(4), 635-653.

Liu, Y., Perfetti, C. A., \& Hart, L. (2003). ERP evidence for the time course of graphic, phonological, and semantic information in Chinese meaning and pronunciation decisions. Journal of Experimental Psychology: Learning, Memory, and Cognition, 29(6), 1231-1247.

Luck, S. J. (2014). An introduction to the event-related potential technique. Cambridge, MA: MIT Press.

Rhee, S. C., Kim, J. A., \& Chang, J. W. (2007). An analysis of the errors produced by English, Chinese and Japanese native speakers with a focus on Korean phonological rules. Journal of Korean Language Education, 18(1), 365-399. 
Appendix 1. Stimuli Words

\begin{tabular}{|c|c|c|c|c|c|}
\hline \multicolumn{2}{|c|}{ Aspiration } & \multicolumn{2}{|c|}{ Liquidization } & \multicolumn{2}{|c|}{ Liason } \\
\hline $\begin{array}{l}\text { Consistent in spelling } \\
\text { to sound }\end{array}$ & $\begin{array}{l}\text { Inconsistent in spelling } \\
\text { to sound }\end{array}$ & $\begin{array}{l}\text { Consistent in spelling } \\
\text { to sound }\end{array}$ & $\begin{array}{l}\text { Inconsistent in spelling } \\
\text { to sound }\end{array}$ & $\begin{array}{l}\text { Consistent in spelling } \\
\text { to sound }\end{array}$ & $\begin{array}{l}\text { Inconsistent in spelling } \\
\text { to sound }\end{array}$ \\
\hline 낳다[나타] & 않다 & 진리[질리] & 실내 & 목욕[모곡] & 단어 \\
\hline 놓다[노타] & 속한 & 달님[달림] & 관리 & 삼월[사뭘] & 잡아 \\
\hline 녹화[노콰] & 쌓다 & 연령[열령] & 진로 & 군인[구닌] & 먹어 \\
\hline 직후[지쿠] & 역할 & 언론[얼론] & 진료 & 녹음[노금] & 집어 \\
\hline 급히[그피] & 특히 & 관련[괄련] & 곤란 & 각오[가고] & 찍어 \\
\hline 극히[그키] & 딱히 & 권리[궐리] & 훈련 & 감옥[가목] & 만약 \\
\hline 국회[구쾨] & 꽃힌 & 근래[글래] & 혼란 & 근육[그뉵] & 불안 \\
\hline 백호[배코] & 밝힌 & 근로[글로] & 산림 & 금액[그맥] & 붙여 \\
\hline 옳다[올타] & 넓힌 & 난리[날리] & 실눈 & 단위[다뉘] & 졸업 \\
\hline 약한[야칸] & 숱한 & 논리[놀리] & 권력 & 반응[바능] & 많이 \\
\hline 잃다[일타] & 뜷다 & 본래[볼래] & 닳는 & 본인[보닌] & 선원 \\
\hline 닿다[다타] & 얽힌 & 분리[불리] & 뜷는 & 분야[부냐] & 순위 \\
\hline 싫다[실타] & 갇힌 & 반란[발란] & 천리 & 복음[보끔] & 식욕 \\
\hline 낙하[나카] & 익힌 & 원래[월래] & 칼날 & 산업[사넙] & 신인 \\
\hline 집행[지팽] & 박해 & 인류[일류] & 윤리 & 근원[그눤] & 연애 \\
\hline
\end{tabular}




\section{국문초록}

\section{한국어 원어민과 일본어-한국어 및 중국어-한국어 이중언어 사용자 간 음운규칙 적용 여부에 따른 단어재인 시 ERP 성분 비교}

\section{원동란 · 심현섭}

이화여자대학교 언어병리학과

배경 및 목적: 본 연구는 음운규칙 적용 유무에 따라 단어재인과정에서 한국어 원어민과 일본어-한국어 이중언어 사용자, 중국어-한 국어 이중언어 사용자 간 차이를 사건관련전위(event-related potential, ERP)를 통해 살펴보고자 하였다. 방법: 한국어 원어민, 일본어한국어 이중언어 사용자, 중국어-한국어 이중언어 사용자를 대상으로 시각자극 제시 이후 들리는 청각자극과 비교하여 음운규칙이 올바르게 적용되었는지에 대해 판단하도록 하는 음운판단과제를 사용하여 진행하였다. 결과: 행동분석 결과, 집단 내 음운규칙 적용 여부에 따른 정반응률과 반응시간에서 모두 유의미한 차이가 나타났다. ERP 분석 결과, 시각자극 제시 후 N250 구간에서 집단 간 유의 미한 차이가 나타났다. 음운규칙 적용 여부에 따라서도 유의미한 차이가 나타났다. 청각자극 제시 후 $\mathrm{N} 400$ 구간에서 음운규칙 적용 유 무에 따라서는 유의한 차이를 보였다. 논의 및 결론: 제 2 외국어로 한국어를 사용하는 이중언어 사용자는 한국어 원어민보다 단어재인 초기에 자소-음소 전환이 활발하게 이루어지지 않으나 단어재인 능력에 차이를 보이지 않음을 알 수 있었다. 따라서 이중언어 사용자 일지라도, 한국어에 노출되는 시간을 늘리고, 음운규칙이 적용되는 단어를 많이 접한다면 한국어 원어민과 동일한 자소-음소 처리를 할수 있다는 가능성을 제시한다.

핵심어: 한국어 단어재인, 이중언어 사용자, ERP, N250, P200, N400

본 연구는 한국연구재단 BK21 플러스의 지원을 받았음(NRF-1-2019-0405-001-1).

\section{참고문헌}

권유안, 남예은, 이윤형(2015). 한국어 시각단어 재인 시 음운정보의 영향: 사건관련전위 연구. 언어과학, 75, 23-42.

권유안, 이윤형(2016). 시각적 단어재인에서 음운부호의 활성화 시점. 언어과학, 76, 1-21.

김충명(2010). 이중언어환경에서의 언어간 부호 전화 수준에 따른 차별적 신경활성화 과정: ERP 연구 말소리와음성과학, 2(4), 3-10.

김태경, 백경미(2015). 중국인 한국어학습자의 음운규칙 적용 양상 연구. 우리말글, 64, 117-151.

이석재, 김정아, 장재웅 (2007). 영어, 중국어, 일본어권 환자의 한국어 음운 규칙 적용과정에서의 음소 산출 오류에 관한 연구. Korean Language Education, 18(1), 365-399.

임유진, 김영태(2008). 단어 읽기 과제에서 초등 2학년과 5학년 아동의 음운규칙 적용능력의 비교. 한국언어청각임상학회, 13(4), 635-653.

조남호(2003). 한국어 학습용 어휘선정 결과 보고서. 서울: 국립국어원.

최서진(2017). 음운변동이 일어나는 의미 단어와 무의미 단어에서의 음운규칙 적용 여부에 따른 단어 재인 시 성인의 ERP 성분 분석. 이화여자대학 교대학원 석사학위논문.

최서진, 심현섭(2019). 한국어 불규칙 단어 재인 시 표기-음운변환 처리과정. 사건관련전위 연구. Communication Sciences \& Disorders, 24(3), 647655 .

허용(2012). 외국인 학습자의 한국어 발음 오류에 대한 음운론적 분석-음운현상을 중심으로-. 한국학논집, 46, 201-232.

\section{ORCID}

원동란(제1저자, 대학원생 http://orcid.org/0000-0002-9753-5065); 심현섭(교신저자, 교수 http://orcid.org/0000-0002-4710-3678) 